\title{
Proactive coping in the teaching profession
}

\section{Žaneta Miháliková Žitňáková}

\begin{abstract}
This article deals with the study of proactive strategies of coping with workload in teaching profession. The main aim was to identify the gender differences in the level of proactive coping with workload using the Proactive Coping Inventory ( $\mathrm{PCl}$ ). Another aim of the paper was to explore the differences in the level of proactive coping of teachers in relation to the length of their teaching practice. Altogether 135 teachers, 112 women (83\%) and 23 men (17\%) participated in the research. The results of our research showed the presence of differences in the level of seeking emotional support between men and women, as well as differences in strategic planning, proactive and reflective coping among teachers depending on the length of their teaching practice.
\end{abstract}

Key words: workload, coping, teacher, proactive coping theory.

\section{Proaktívne zvládanie zát’aže v profesii učitel’a}

\begin{abstract}
Abstrakt
Predložený príspevok sa zaoberá skúmaním proaktívnych stratégií zvládania zátaže u učitel'ov. Hlavným ciel'om práce bolo zistit’ medzipohlavné rozdiely v úrovni proaktívneho zvládania zátaže pomocou Inventára proaktívneho zvládania zátaže. Ďalším ciel'om práce bolo preskúmat' rozdiely v úrovni proaktívneho zvládania zátłaže u učitel'ov v závislosti od dížky ich pedagogickej praxe. Celkovo sa výskumu zúčastnilo 135 učite-
\end{abstract}


lov, 112 žien (83\%) a 23 mužov (17 \%). Výsledky nášho výskumu preukázali prítomnost' rozdielov v úrovni vyhladávania emocionálnej podpory medzi mužmi a ženami a tiež rozdiely v oblasti strategického plánovania, proaktívneho a reflektívneho zvládania zátaže u učitelov v závislosti od dĺžky ich pedagogickej praxe.

Klúčové slová: zátaž, zvládanie, učitel', teória proaktívneho zvládania.

DOI: 10.5507/epd.2021.001

\section{Introduction}

The results of many foreign and domestic research studies confirm that the teaching profession is one of the most demanding. The teacher is expected to develop skills in pupils to successfully cope with rapid changes in social, personal and later also work life. If a teacher can fulfil this requirement, it is extremely important for these professionals to be able to cope effectively with the workload attributed to this profession. Therefore, in this work, we have focused on the detection of proactive workload management, which enriches the investigation of coping with the perspective of positive strength in man.

\section{Workload and stress in the teaching profession}

As Bratská (2001) states, we encounter various language equivalents or similar expressions for the terms stress and workload in different professional psychological texts. According to Mikšík (1969, in Bratská, 2001) as a supporter of a different understanding of these terms, the concept of workload in comparison with other terms contains an aspect of unity of external influences and internal conditions. Mikšík (1969, in Bratská, 2001) divides the workload into four stages. The first stage is a "common workload" where no mismatch between the pressure of the external environment and the individual's ability to create counter pressure exist. The second stage is the so-called "increased workload", which is linked to situations in which the individual is not able to cope with the usual ways of acting and responding. The third level corresponds to the so-called "limit workload", in which the external environment places greater demands on the individual than are their equipment and readiness to handle them. At this stage, we are no longer talking about the positive effects of workload. The last, fourth stage of workload is "extreme workload" where an individual is unable to develop an effective counterbalance to to the claims of their environment and they give in or become vulnerable. The term stress is recommended by Daniel (1971, in Bratská, 2001, p. 30) "to use in cases of physical stress, respectively, where situations seriously compromise the 
integrity and life of the individual." In the case of moderate and lighter stress, the author considers the use of the term workload to be appropriate. Heretik \& kol. (2016) define stress as the reaction of the organism to excessive workload. Despite some justification leading to different definitions of the concepts of the terms workload and stress, we did not further distinguish these terms for the purposes of our work.

Řehulka \& Řehulková (1998) divide the workload of the teaching profession into physical and mental, while the mental workload is further divided into sensory, mental and emotional work-load. Workload tolerance is individually variable. It is determined by many internal and external factors. The teacherss personality in all its dynamics and structure is an important moderator of the workload management process, as well as their life experiences, perceived social support and others. According to Paulík (1999, in Kubáni, 2002, p. 93) "the teaching profession is demanding especially in terms of the size of the requirements expressed by the teacher's subjective experience. On average, women evaluate their workload higher than men." Miltaková (2004, in Baranovská \& Ručková, 2012) in her research involving 136 secondary school teachers concluded that $89.4 \%$ of teachers experienced a strong to extremely strong workload, but this was not related to the length of their practice. Compared to teachers at primary and higher education, according to research by Gulišová (2013), teachers at secondary schools feel the highest level of mental stress. Increased workload in teachers' work environments can have negative psychological and social impacts in the in the long term. It can negatively affect the quality of life and contribute to the development of some chronic diseases. Čecho \& Hudečková \& Švihorová (2018) state that "professional stress in teacher's job is associated with an increase in the incidence of health problems in relation to work and it is considered a major factor in the development of burnout syndrome." According to Míček \& Zeman (1997, p. 22), under the influence of stress teachers can experience:

1) at the psychological level there is a disproportional level of wear, learned helplessness, loss of contact with possible sources of strength recovery or even the so-called "Teacher's upsetting",

2) at the level of consciousness of the teacher, mental noise appears in the form of fragments of unprocessed past impressions with emotional undertones, which disturb the concentration of attention;

3) at the level of interpersonal relationships of the teacher, unnatural and convulsive relationships with others, a tendency to look at others in a negative light, but also relativization of relationships could be observed.

The concept of Hennig and Keller (1996, p. 1996) provides a general overview of the symptoms of burnout syndrome in teachers, manifesting itself in four levels:

1) at the psychological level: there is a negative image of one's own abilities, a negative attitude towards students and parents, a lack of interest in professional issues,

2) at the emotional level: there is depression, feelings of helplessness, lack of recognition, self-pity, irritability, nervousness, 
3) at the physical level: appearance of rapid fatigue, increased susceptibility to disease, vegetative problems, headaches, muscle tension, etc.,

4) at the social level: loss of educational involvement and efforts to help students, limiting contact with parents to a minimum.

\section{Coping with workload and stress}

Various techniques used by individuals to cope with stressful situations are called coping strategies. Some authors use the terms coping strategy and coping style as synonyms. According to other authors, coping styles, in contrast to coping strategies, represent transitionally consistent and more permanent ways of coping with different types of stressful situations (Mareš, J., 2001). In connection with the clarification of these concepts, many experts strictly distinguish the management processes and the defensive processes, which are, according to Haan (1977, in Ruiselová, 2006, p. 11), "rigid, reality - distorting and driven by stimuli from the past." The behavior associated with coping processes, on the other hand, is, according to Haan (1963, 1977, in Ruiselová, 2006, p. 11), "purposeful and flexible, reality-oriented, future-oriented, and determined by preconscious and conscious elements." In relation to load management strategies, Amirkhan (1990, in Baumgartner, 2001, p. 197) distinguishes:

1) instrumental strategy, focus on the problem (active solution),

2) a strategy of seeking social support, turning to other people - seeking advice, help, human contact,

3) avoidance strategy (physical and psychological avoidance), escape, retreat.

The classification based on mobilized coping sources was proposed by Poon and Lau (1999, in Greenglass \& Lukavský \& Šolcová. 2006, p. 149), distinguishing between:

1) problem solving planning,

2) reassessment of the situation (mobilization of internal resources),

3) seeking social support (mobilization of external resources),

4) avoidance.

Beehr and McGrath (1996, in Greenglass \& Lukavský \& Šolcová. 2006, 155) defined five types of coping:

1) reactive: focused on current or past damage,

2) anticipatory: focused on immediate threats in the near future,

3) preventive: focused on uncertain potential threats in the distant future,

4) proactive: providing challenges that lead to self-development. 
The differences in coping strategies between men and women have been researched by Baumgartner \& Frankovský, Endler \& Parker (1990, in Oškrdová, 2007), or Lovaš (1997). As one of the specifics of Slovak education system is its persistent feminization, the investigation of possible differences in the field of coping between men / teachers and women / teachers is part of many researches. Hupková \& Petlák (2004) distinguish six developmental phases of the formation of the teacher's personality (orientation, preparatory, integration and adaptation, phase of professional stabilization and phase of professional fading, selfregulatory phase). In each of these phases, the teacher may face different types of stressors, due to the specific characteristics and tasks of each phase. In addition, the growing experience in the teaching profession can lead to improvement of coping skills. However, some researches (Fialová \& Schneiderová, 1998) point to a higher risk of burnout syndrome in professionally older teachers in secondary schools, which according to Schwarz \& Tauber (2002) is not compatible, e. g. with proactive coping. Research in the regular population (Janke \& Erdmann, 2003) has shown that with increasing age (ranging from 20 to 49 years of age), the strategy of preservation, for example, appears less frequently. In connection with the high number of teachers in retirement age in Slovak education, in our opinion, it is necessary to devote space to examining the specifics of teachers' coping in terms of the length of their teaching practice.

\section{Theory of proactive coping}

As Joseph (2017) states, the positive changes that people can experience describe various concepts such as the search for profit, growth following adversity, growth associated with stress, etc. Ruiselová \& Prokopčáková (2006, in Ruisel et al, 2006) rank the theory of proactive coping among the newer approaches to coping, which have in common the orientation of the personality to the challenge. According to Schwarzer \& Taubert (2002) by extending the coping process to goal tracking and self-development, the theory of proactive coping provides a more comprehensive and realistic view of a person coping with different life situations compared to previous theories. The possibility of a person to approach stressful situations proactively is being considered in the context of the concept of Beeher and Mc. Grath (1996, in Greenglass \& Lukavský \& Šolcová, 2006), which includes a previously derogated factor of time. In a relatively short period of time, the theory of proactive coping has undergone several modifications of content, which have continually added new context and facts supporting its validity. The concept of Schwarzer and Taubert (2002) includes not only reactive, anticipatory, preventive, but also proactive coping. In our work we proceed from the Greenglass approach (2002, in Greenglass \& Lukavský \& Šolcová, 2006), according to 
which the innovativeness of proactive coping in comparison with traditional concepts lies in three crucial aspects:

Proactive coping:

1) is directed towards the future, in contrast to traditionally conceived coping focused on stressful situations that have already taken place, in terms of preventive coping, is an effort to build resources that will lead to achievements of goals and personal growth;

2) focuses on the achievement of the objectives set, with the presence of the vision, requirements and risks that are assessed in the view of these objectives;

3) the motivation of proactive coping is largely positive as situations are evaluated as challenges.

In his research, Schwarzer (2002) found a positive relationship between the evaluation of difficult situations as challenges and the high level of proactivity of teachers in Germany. Taubert (1999, in Schwarzer \& Taubert 2002) demonstrated a positive correlation between proactive coping and perceived self-efficacy, which Křivohlavý (1998, p. 75) defines as "the belief that a person is able to determine and influence his mental states and behavior, to influence their surroundings and to achieve the desired results". As further reported by Tauber (1999, in Schwarzer \& Taubert 2002), the proactive coping scale is negatively associated with neuroticism. One of the pillars of our research assumptions was the finding of Schwarzer \& Taubert (2002) that burnout of teachers is a relevant construct for validation because it should not be compatible with proactive coping. The research by these authors revealed a significant decrease in the incidence of burnout with an increase of the level of proactive coping, with the group of proactive teachers examined reporting less emotional exhaustion and less cynicism. Other findings by Schwarzer \& Taubert (2002) show that a high level of proactive coping among teachers is associated with high evaluation and perception of challenge, feelings of greater personal recognition and success. Conversely, a low proactive coping level is associated with a high evaluation and perception of harm and loss.

\section{Research methodology}

Within the research investigation, the objective of the research was set and the appropriate methodology was chosen to verify the postulated research hypotheses. The research sample consisted of secondary school teachers from five districts of Slovakia. 


\subsection{Objective of research, research hypotheses}

The main objective of the research was to find gender differences in the level of proactive coping among secondary school teachers and also the differences in relation to their length of teaching practice.

We postulated the following research hypotheses:

$\mathrm{H} 1$ : We assume that there are gender differences in the level of proactive stress management in the group of teachers.

$\mathrm{H} 2$ : We assume that there are differences in the level of proactive coping in the group of teach-ers depending on the length of their teaching practice.

\subsection{Research method}

As a research tool, we chose the Proactive Coping Inventory PCl designed by Greenglass (2002, in Greenglass \& Lukavský \& Šolcová, 2006), to be used also for the purpose of our research. $\mathrm{PCl}$ contains 55 items in total, which are structured into 7 subscales: Proactive situation solving (14 items), Reflective situation solving (11 items), Strategic planning (4 items), Preventive situation management (10 items), Instrumental search Support (8 items), Finding emotional support (5 items) and Avoiding the solution of a situation (3 items). The individual items have the character of first-person communication sentences, which respondents evaluate using a four-point scale $(1-$ not true at all, 2 - hardly true, 3 - a little more true, 4 - completely true), depending on how these statements correspond to their feelings in different types of situations. $\mathrm{PCl}$ shows reasonably good psychometric properties including internal consistency for each subscale with a's ranging from .61 to .85 . In general, each of the subscales showed good item-total correlations. (Greenglass, Schwarzer, \& Taubert, 1999). As stated by Greenglass \& Lukavský \& Šolcová (2006), the psychometric properties of the Czech version of the questionnaire are comparable to the original version. The psychometric properties of the Slovak version of the questionnaire were investigated by Sollár \& kol. (2019). According to the authors, the internal consistency of the scales is in all cases low $a=\omega=.55-.78$. The questionnaire scales correlate with each other. The authors leave as an open question whether this is a problem influenced more by translation or by the construction of the original scale. In Slovakia a number of authors worked with PCl e. g. Sollárová \& Sollár (2009), Ficková (2009), Ruiselová \& Pro- kopčáková (2010). The questionnaire was administered by mail, with a return rate of $55 \%$. 


\subsection{Research sample}

135 secondary school teachers in Slovakia voluntarily participated in the research, of them $83 \%$ were women and $17 \%$ were men. Teachers from grammar schools $(n=78)$, a joint secondary school $(n=19)$, a pedagogical and social academy $(n=16)$, a nursing school $(n=12)$ and an associated secondary school $(n=10)$ were represented in the research. The age range of respondents was from 21 to 65 years, the average age of respondents was 42 years of age. We divided the teachers into four categories according to the length of their teaching practice. The first category (1-5 years of experience) consisted of 31 teachers, the second category (6-15 years of experience) consisted of 41 teachers, the third category (16-25 years of experience) was represented by 23 teachers and the fourth category ( 26 years and more) consisted of 40 teachers.

\subsection{Data processing methods}

The SPSS v.16 statistical program was used for data processing. We used descriptive statistic methods to describe individual variables from our research. To determine the differences be- tween men and women at the level of proactive coping, we used the T-test for two independent selections, and to explore the differences at the level of proactive coping of teachers depending on their length of teaching practice, we used one way ANOVA analysis with significance level $p<0.05$. We used the Levene test to test for equality of variance.

\subsection{Results}

Table 1

Descriptive statistics - individual types of coping in men and women

\begin{tabular}{|l|c|c|c|c|c|}
\hline & Gender & N & Mean & Std. & Std. \\
\hline \multirow{2}{*}{ Proactive coping } & men & 23 & 43.56 & 5.70 & 1.18 \\
\hline \multirow{2}{*}{ Reflective coping } & women & 112 & 45.02 & 4.30 & .40 \\
\hline \multirow{2}{*}{ Strategic planning } & men & 23 & 35.34 & 3.61 & .75 \\
\hline \multirow{2}{*}{ Preventive coping } & women & 112 & 34.63 & 4.56 & .43 \\
\hline & men & 23 & 12.04 & 2.22 & .46 \\
\hline & women & 112 & 11.70 & 2.81 & .26 \\
\hline & men & 23 & 30.34 & 5.36 & 1.11 \\
\hline
\end{tabular}




\begin{tabular}{|l|c|c|c|c|c|}
\hline & Gender & N & Mean & Std. & Std. \\
\hline \multirow{2}{*}{ Search for instrumental support } & men & 23 & 24.08 & 4.16 & .86 \\
\cline { 2 - 7 } & women & 112 & 25.30 & 4.40 & .41 \\
\hline \multirow{2}{*}{ Search for emotional support } & men & 23 & 12.78 & 2.87 & .59 \\
\cline { 2 - 7 } & women & 112 & 14.48 & 3.17 & .30 \\
\hline \multirow{2}{*}{ Evasive (avoiding) coping } & men & 23 & 7.96 & 2.18 & .45 \\
& women & 112 & 7.56 & 2.20 & .20 \\
\hline
\end{tabular}

From the data in tab. 1 results that the value of the average level of seeking emotional support in the group of men reaches the value $M=12.78$ and $M=14.48$ in the group of women.

Table 2

Comparison of the level of individual types of coping in men and women

\begin{tabular}{|l|c|c|c|c|c|c|}
\hline & \multicolumn{2}{|c|}{$\begin{array}{c}\text { Levene's Test for } \\
\text { equality of variances }\end{array}$} & \multicolumn{4}{|c|}{ t-test for Equality of Means } \\
\cline { 2 - 8 } & $\mathbf{F}$ & Sig. & t & df & Sig. (2-tailed) & Mean Difference \\
\hline Proactive coping & 3.284 & .072 & -1.398 & 133 & 0.164 & -1.46 \\
\hline Reflective coping & 1.903 & .170 & .705 & 133 & 0.482 & 0.71 \\
\hline Strategic planning & 2.853 & .094 & .542 & 133 & 0.589 & 0.33 \\
\hline Preventive coping & 0.765 & .383 & .345 & 133 & 0.731 & .37 \\
\hline Seeking instrumental support & 0.012 & .914 & -1.218 & 133 & 0.226 & -1.21 \\
\hline Seeking emotional support & 1.464 & .228 & -2.371 & 133 & 0.019 & -1.69 \\
\hline Evasive (avoiding) coping & 0.049 & .825 & .782 & 133 & 0.436 & 0.39 \\
\hline
\end{tabular}

The results shown in tab. 2 imply that the hypothesis $\mathrm{H} 1$ on the existence of gender differences in the level of proactive coping of teachers has been confirmed. Based on the results shown in tab. 2 we can state the existence of a difference between men and women in the search for emotional support. 


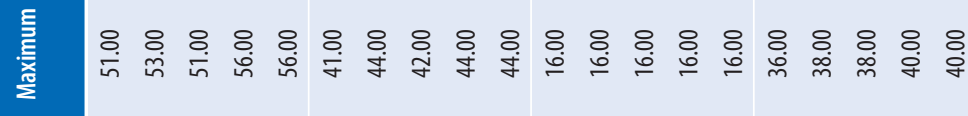 \\ 言 庐}

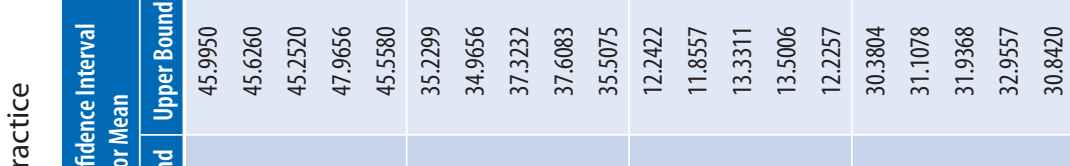

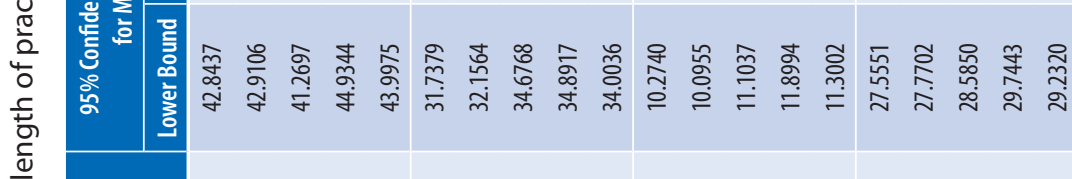

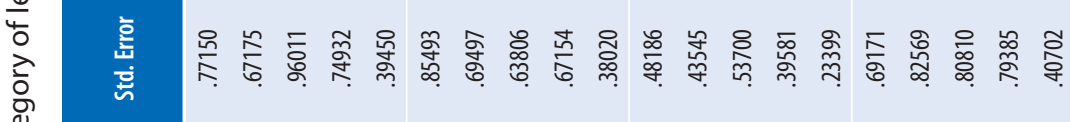

苛

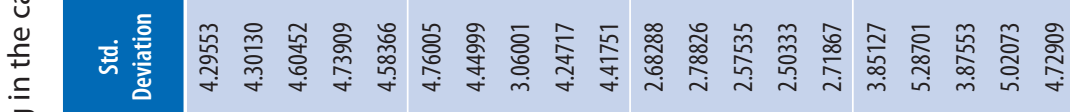

흥

2

$\frac{\overline{0}}{\frac{0}{2}}=$

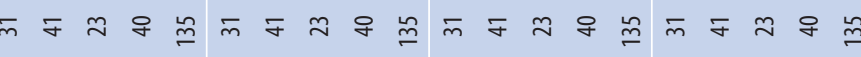

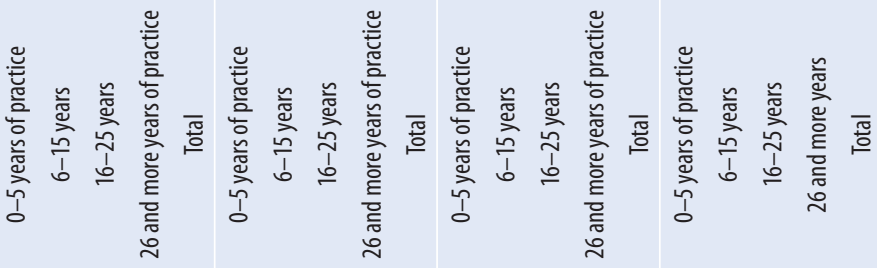




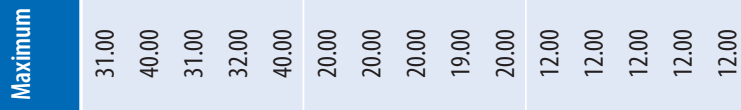 \\ 蒿}

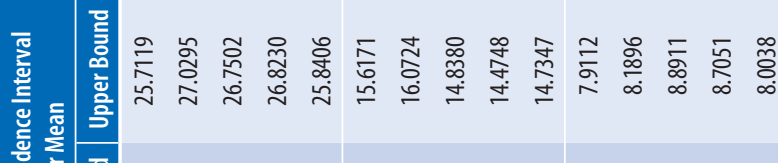

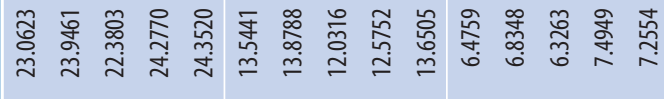

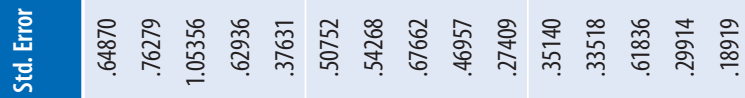

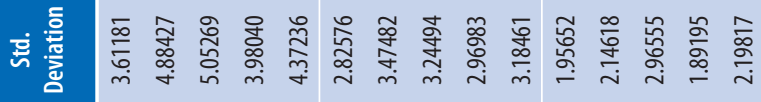

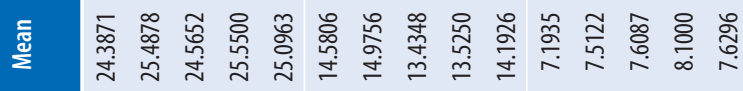

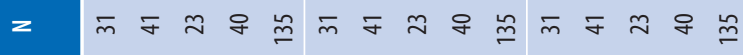

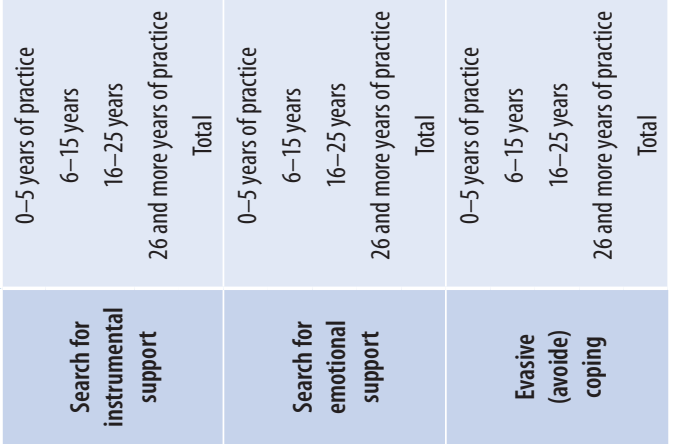


Based on the results shown in tab. 4 and in tab. 5, we can conclude that the hypothesis $\mathrm{H} 2$ on different level of proactive coping of teachers depending on the length of their teaching practice has been confirmed.

\section{Table 4}

Result of analysis of variance of simple classification according to the length of practice

ANOVA

\begin{tabular}{|l|c|c|c|c|c|c|}
\hline & & $\begin{array}{c}\text { Sum of } \\
\text { Squares }\end{array}$ & df & Mean Square & F & Sig. \\
\hline \multirow{2}{*}{ Proactive coping } & Between Groups & 179.401 & 3 & 59.800 & & \\
& Within Groups & 2635.932 & 131 & 20.122 & 2.972 & .034 \\
& Total & 2815.333 & 134 & & & \\
\hline \multirow{2}{*}{ Reflective coping } & Between Groups & 233.594 & 3 & 77.865 & & .006 \\
& Within Groups & 2381.339 & 131 & 18.178 & 4.283 & \\
\hline \multirow{2}{*}{ Strategic planning } & Total & 2614.933 & 134 & & & \\
& Between Groups & 73.191 & 3 & 24.397 & & .018 \\
& Within Groups & 917.224 & 131 & 7.002 & 3.484 & \\
\hline
\end{tabular}

* Due to the limited scope of the paper, we present in tab. 4 and in tab. 5 only those PCI scales in which we recorded statistically significant differences.

We state the existence of statistically significant differences between the categories of teachers according to the length of their pedagogical practice in three subscales of the questionnaire (tab. 5):

- we state that there is a statistically significant difference in the subscale of proactive coping between the category of teachers with 16 to 25 years of teaching practice and the category of teachers with 26 and more years of teaching practice where the level of proactive coping is higher,

- in the subscale of reflective coping between the category of teachers with a length of teaching practice of 0 to 5 years and the category of teachers with a length of teaching practice of 26 or more years of practice with a higher level of reflective coping and also between categories of teachers with a length of teaching practice of 6 to 15 years, 26 years and more $(F=4.283, p=0.006)$, for which the level of reflective coping is higher,

- in the subscale of strategic planning between the category of teachers with a length of teaching practice of 6 to 15 years and 26 or more years of teaching practice $(F=3,484, p=0,018)$. 


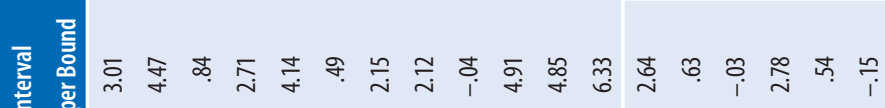

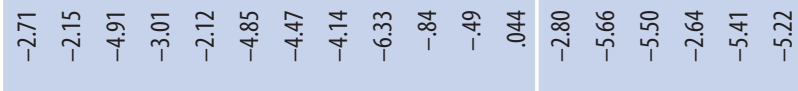

岂

䍃

崩

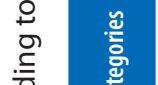

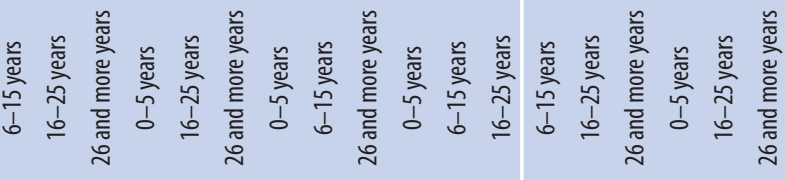

응 흥

ডั

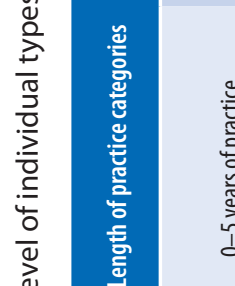

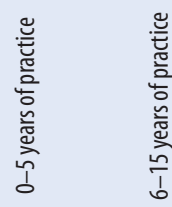

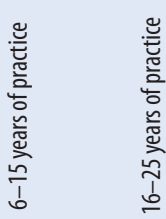

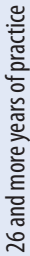

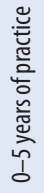

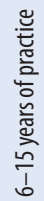

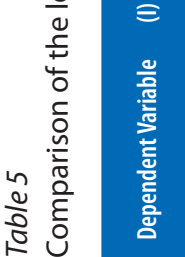

을

흘 


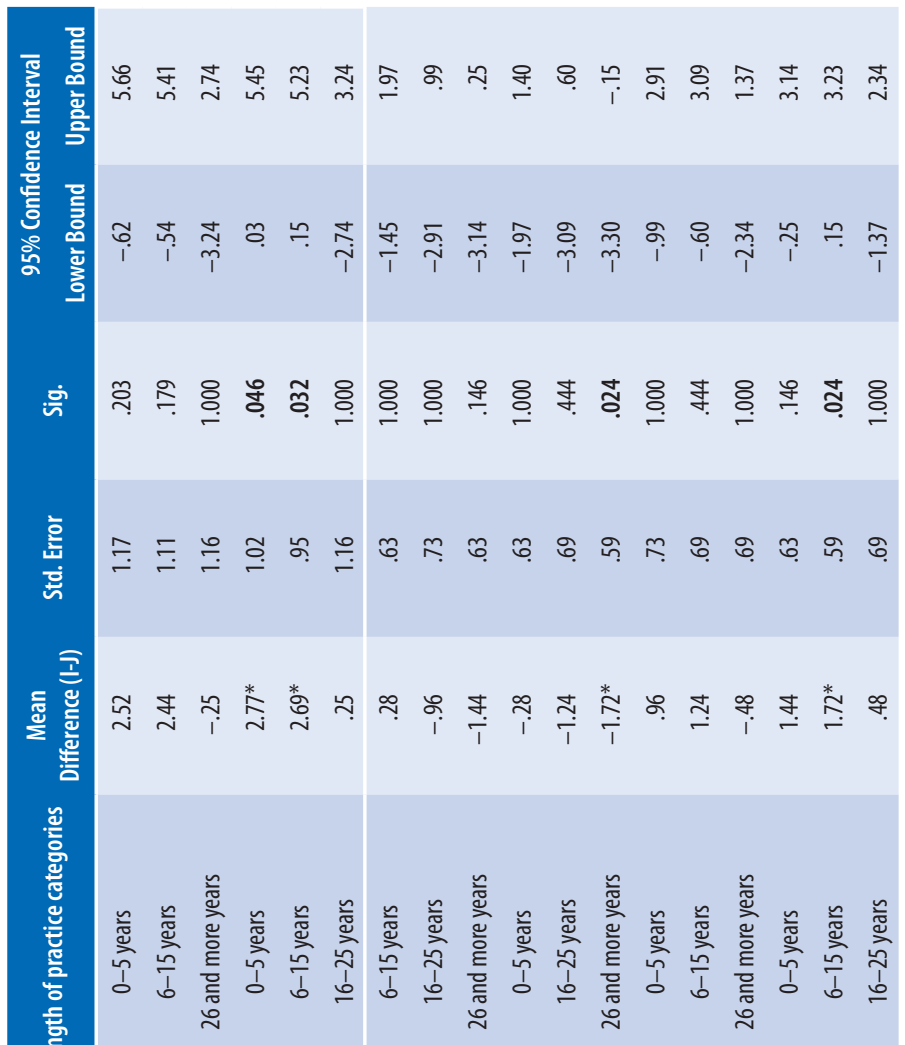




\section{Discussion}

In our research, we showed a difference between men and women in the level of seeking emotional support, as this was significantly higher for women. Our findings fully correspond to the results of Greenglass \& Schwarzer \& Taubert (1999) as well as the results of Greenglass \& Lukavský \& Šolcová (2006), who also demonstrated these differences in coping with emotional support between men and women. Similarly, according to Baumgartner \& Frankovsky (1997), women in a situation of stress tend to seek contact with other people. Likewise, Míček (1988) advises conversation with colleagues, partners or children as a frequent means of consciously relieving mental tension in teachers.

Other findings in our research show proven differences in the subscale of proactive coping between the group of teachers with the length of teaching practice ranging from 16 to 25 years and the group of teachers with the experience ranging from 26 to more years, which achieved the highest average score of the four assessed groups. We noticed further differences between the groups of teachers in the subscale of reflective coping. In this area, differences were present between the group of teachers with a length of teaching experience of 0 to 5 years and the group of teachers with a length of teaching experience of 26 years or more in which the level of reflective coping is higher. We also found differences in the area of reflective coping between the categories of teachers with a length of teaching experience of 6 to 15 years and 26 or more years. Also in the field of reflective coping, its level is higher in the group of teachers with a length of teaching practice of 26 years and more. We also found differences between the examined groups of teachers in the subscale of strategic planning, especially between the group of teachers with a teaching practice of 6 to 15 years and the group of teachers with a teaching practice of 26 years or more, for which the level in the subscale of reflective coping reached higher values.

Similarly, Sollár \& Sollárová (2009) report a higher preference for proactive coping in the oldest research group in their research.

The results of our research are not easy to interpret due to the limitations arising from the nature of the research set. We acknowledge the fact that the factor of the length of pedagogical practice together with the achieved pedagogical mastery, life and work experience can gradually lead teachers to build a repertoire of behavioural patterns based on a positive view of the world. The results of our research thus indicate that older, experienced teachers in our research remain open to innovation and show a desire to further personal development. 


\section{Conclusion}

The paper presents the results of a research to determine whether there are significant gender differences in the level of proactive coping among teachers. We also focused on identifying differences in the level of proactive coping depending on the length of teachers' teaching practice.

Significant differences between men and women in our research were confirmed in the subscale of search for emotional support, while women in our research reached a higher level in this area. In our research, we demonstrated differences between categories of teachers with different lengths of teaching experience in the subscale of proactive coping, reflective coping and strategic planning. We noticed differences in the subscale of proactive coping between the group of teachers with pedagogical practice from 16 to 25 years and the group of teachers with pedagogical practice ranging of 26 years and more. We found differences in the field of reflective coping between teachers with the length of teaching practice of 0 to 5 years and teachers with the length of teaching practice of 26 or more years, as well as between teachers with the length of teaching practice of 6 to 15 years and the teachers with the length of practice of 26 and more years. In both cases, a higher level of reflective coping was recorded in the group of teachers with teaching experience of 26 years and more. In the subscale of strategic planning, we demonstrated differences between the group of teachers with the length of teaching practice of 6 to 15 years and the group with a length of teaching practice of 26 years and more. Also in the subscale of strategic planning, its level was higher in the group of teachers with the length of teaching experience of 26 and more years. The findings obtained in our research set indicate a trend of increasing levels of proactive coping with increasing years of pedagogical practice of teachers, bringing a possible positive view of coping strategies of the oldest professional group of teachers.

Although the conclusions of our research cannot be generalised to the whole population of teachers, the partial results create space for the formulation of some practical recommendations. Implementing the results of our research into practice requires orienting school policy towards creating conditions that support teachers' health. According to Act no. 138/2019 Coll. on pedagogical employees and professional employees, these are entitled, for the needs of professional development, to time off work with compensation of salary in the range of five working days in a calendar year. In comparison, teachers in some EU countries can use "Sabbatical leave", ie study leave with a job guarantee and financial coverage of living and study costs. Turek (2008) advises this form of study leave to the possibilities of delaying the burnout syndrome in teachers. We consider the creation of a diverse range of anti-stress programs and supportive training to be beneficial in the context of teacher's mental health promotion. It turns out that these programs need to be created with regard to the real requirements of teachers, the length of their teaching experience, the focus of the school, or the 
specifics of individual regions in which teachers work. According to Andrášiová (2016, in Heretik et al.) in stressful life situations, personality characteristics are reflected in balancing coping strategies and influence their choice. Therefore Daniel (1997) brings an interesting proposal, when he recommends taking into account the personality characteristics of applicants for teacher training as part of the prevention of workload stress.

\section{Resources}

Baranovská, A. \& Ručková, G. 2012. Vzt’ah medzi osobnostnými charakteristikami a subjektívne vnímanie zátaže učitel'ov pôsobiacich na základných a stredných školách. In Klinická psychologie a osobnost. [online]. Available at: https://digilib.phil.muni.cz/bit-stream/handle/11222.digilib/ 125964/1_KlinickaPsychologie_01-20121_10.pdf?sequence=1

Baumgratner, F. (2001). Zvládanie stresu - coping. In Slaměník, I., \& Výrost, J. (2001). Aplikovaná sociální psychologie (Vol. 2). Praha: Grada.

Baumgartner, F. \& Frankovský, M. (1997). K problémom zist'ovania stratégií riešenia náročných situácií. Psychológia a patopsychológia dietatáa. 32(2), 155-160.

Bratská, M. (2001). Zisky a straty v zátažových situáciách, alebo príprava na život. 1. vyd. Bratislava: Trade Leas.

Čecho, R., Hudečková H. \& Švihrová, H. (2018). Dotazník TSI - Teacher Stress Inventory: validácia slovenskej verzie. [online]. Available at: https://www.researchgate.net/publication/336150089_ Dotaznik_TSI_Teacher_Stress_Inventory_validacia_slovenskej_verzie

Čecho et al. (2018). Hodnotenie psychickej pracovnej zátaže učitel'ov vybraných základných škôl. In Jurkovičová, J. \& Štefániková, Z. (Eds.). Životné podmienky a zdravie. Bratislava: UK. [online]. Available at: https://www.fmed.uniba.sk/fileadmin/lf/sucasti/Teoreticke_ustavy/Ustav_ hygieny/Webpic/Zborniky/ZPaZ_2018.pdf

Daniel, J. (1997). Burnout v učitel'skom povolaní a jeho zvládanie. Psychológia a patopsychológia dietata. 32(2), 183-187.

Ficková, E. (2009). Reactive and proactive coping with stress in relation to personality dimensions in adolescents. Studia Psychologica, 51(2-3), 149-160.

Fialová, I. \& Schneiderová, A. (1998). Syndrom vyhoření v profesní skupině středoškolských učitelů. In Řehulka, E., Řehulková, O., \& Psychologický ústav (Akademie věd ČR). Učitelé a zdravi 1. Brno: Pavel Křepela.

Greenglass, E. R. \& Schwarzer, R. \& Taubert, S. et al. (1999). The Proactive Coping Inventory (PCI): A multidimensional research instrument. [online]. Available at: https://pdfs.semanticscholar.org/ f5ab/54d3d33f4fa8f96652b6d904967547c6b96d.pdf

Greenglass, E. R. \& Lukavský, J. \& Šolcová, l. (2006). Dotazník proaktívniho zvládaní životných nároků. Československá psychologie. L(2), 148-162.

Gulišová, L. (2013). Vnímaná psychická zátaž v povolaní učitela a jej porovnanie na úrovni jednotlivých stupňov.

Heretik, A., et al. (2016). Klinická psychológia. Nové Zámky: Psychoprof.

Hupková, M. \& Petlák, E. (2004). Sebareflexia a kompetencie v práci učitela. Bratislava: Iris.

Janke, W. \& Erdmannová, G. (2003). Strategie zvládání stresu - SVF 78. Praha: Testcentrum.

Joseph, S. (2017). Co nás nezabije. Možnosti postraumatického růstu. Praha: Portál.

Křivohlavý, J. (1998). Jak nestratit nadšení. Praha: Grada Publishing.

Lovaš, L. (1997). Vplyv situácie a pohlavia na správanie v náročných životných situáciách. Psychológia a patopsychológia diet'at'a. 32(2), 144-148. 
Mareš, J. (2001). Zvládaní zátěže pomocí strategií záměrného sebeznevýhodňování. Československá psychologie. XLV(4), 311-322.

Míček, L. (1988). Sebevýchova a duševní zdraví. Praha: SPN.

Míček, L. \& Zeman, V. (1997). Učitel'a stres. 2. vyd. Opava: Vademecum.

Oškrdová Z. (2007). Zvládaní zátěže u učitelů: Diplomová práca. Brno: MU.

Paulík, K. (1998). Co obtěžuje učitele různych typů škol. In Řehulka, E., Řehulková, O., \& Psychologický ústav (Akademie věd ČR). Učitelé a zdraví 1. Brno: Pavel Křepela.

Řehulka, E. \& Řehulková, O. (1998). Problematika tělesné a psychické záteže při výkonu učitelského povolání. In Řehulka, E., Řehulková, O., \& Psychologický ústav (Akademie věd ČR). (1998). Učitelé a zdraví 1. Brno: Pavel Křepela.

Ruisel, I. et al. (2006). Úvahy o inteligencii a osobnosti. [online]. Available at: https://psychologia.sav.sk/ upload/Ruisel_Uvahy\%20o\%20inteligencii\%20a\%20osobnosti.pdf

Ruisleová, Z. et al. (2006). Štýly zvládania zátaže. Bratislava: Slovak Akademic Press. [online]. Available at: http://www.psychologia.sav.sk/zvladanie

Ruiselová, Z. \& Prokopčáková, A. (2010). Counterfactual thinking and proactive coping. Studia Psychologica, 52(4), 291-299.

Schwarzer, R. \& Taubert, S. (2002). Tenacious goal pursuits and striving toward personal growth: Proactive coping. In Frydenberg, E. (Ed.). Beyond coping: Meeting goals, visons and challenges. Oxford: Oxford Universtiy Press. [online]. Available at: https://www.researchgate.net/publication/251415584_Tenacious_Goal_Pursuits_and_Striv-ing_Toward_Personal_Growth_ Proactive_Coping

Sollár, T. \& kol. (2019). Psychometrické vlastnosti slovenskej verzie dotazníka Proactive Coping Inventory: konštruktová validita a vnútorná konzistencia. Československá psychologie, 63(2), 193-209.

Sollárová, E., \& Sollár, T. (2009). Proactive coping from the perspective of age, gender and education. Studia Psychologica, 51(2-3), 161-165.

Turek, I. (2008). Didaktika. 1. vyd. Bratislava: lura Edition.

Zákon č. 138/2019 o pedagogických zamestnancoch a odborných zamestnancoch a zmene a doplnení niektorých zákonov.

\section{Contact:}

Mgr. et Mgr. Žaneta Miháliková Žitňáková

Department of Special Education

Faculty of Education, Comenius University in Bratislava

Račianska 59, Bratislava 81334

Slovak Republic

e-mail: zitnakova3@uniba.sk

Mgr. et Mgr. Žaneta Miháliková Žitňáková is an external student of the PhD study program Special Education at the Faculty of Education of Comenius University in Bratislava. In her dissertation thesis and realised investigations she deals with the attitudes, values and self-evaluation of pupils with developmental learning disabilities. She works as a psychologist at the Center of Special Education Counselling in Kremnica, where she focuses primarily on children and pupils with hearing impairment, communication disability, developmental learning disabilities and multiple disabilities. 